Gennady Zaikov ${ }^{1}$ Klara Gumargalieva² and Marina Artsis ${ }^{1}$

\title{
BIODEGRADATION OF POLYMERIC MATERIAL AND ADHESIVE PROPERTIES OF CELLS OF MICROORGANISMS
}

\author{
${ }^{1}$ N . M . Emanuel Institute of Biochemical Physics, Russian Academy of Sciences \\ 4 Kosygin str., 119334 M oscow, Russia; Chembio@sky.chph.ras.ru \\ ${ }^{2} \mathrm{~N}$. N. Semenov Institute of Chemical Physics, Russian Academy of Sciences \\ 4 Kosygin str., 119991 M oscow, Russia
}

Received: July 02, 2009 / Revised: October 10, 2009 / Accepted: January 13, 2010

(c) Zaikov G., Gumargalieva K., Artsis M., 2010

\begin{abstract}
The chemical composition of cell membranes of microscopic fungi destroying polymeric materials is analyzed. The concentrations of the major chemical components phospholipids, glycans, and amines - in nine types of fungi are estimated. The measured ratios of these components provide an estimate of the hydrophobic properties of conidia, controlling microorganism adhesion to polymer surface and subsequent degradation of polymeric materials.
\end{abstract}

Keywords: biodegradation, polymer, materials, adhesive, properties, cells, microorganisms.

\section{Introduction}

Biological stability of polymeric materials hinges on a variety of factors, in particular, on composition and properties of the contacting surfaces of polymers and microorganisms, controlling the early stage of a complex process - biodegradation. The strength and origin of adhesive bonds depend, in turn, on the chemical nature of substances secreted by cells of microorganisms, reducing biodegradation to conventional chemical decomposition.

Cell membranes of microscopic fungi control most vital aspects of cell activity, from adhesion to cell fission and growth. This should be taken into account when predicting biological stability of polymeric materials which primarily depends on the ability of conidia - microstructural units of microscopic fungi - to adhere to surfaces.

The modern concept is that conidial membranes consist of several layers, the number and thickness of which depend on the conditions of their growth. A cell membrane contains polysaccharides (mostly, chitin and glycans), lipids, proteins and pigments [1,3]. The basic method of exploring the composition of a cell membrane is chemical analysis which is labour-consuming and, in certain cases, gives no way of identifying chemical constituents of the membrane completely, because membranes are destroyed in the course of analysis.
In recent years, it has become usual to analyze the chemical composition of membranes by a non-destructive method, namely, by multiple attenuated total reflectance spectroscopy in the infrared spectral range (IR MATR), which was first successfully applied in [4-7] to qualitatively identify the chemical species contained in membranes of yeast cells.

This study was accomplished with an intent to determine quantitative composition of the surface layer of conidia by IR MATRS and correlate the chemical composition with hydrophobic properties of their cells.

\section{Experimental}

\subsection{M aterials}

The objects of investigation were conidia of the following microscopic fungi: Aspergillus niger, Aspergillus terreus, Penicillium chrysogenium, Penicillium funiculosum, Penicillium cyclopilun, Paecilomyces varioti, Thrichoderma viride, Chaetomicin globusum and Aspergillius flavus. This set of microorganisms is incorporated in all-union state standard analysis of polymers for their biological stability.

\subsection{M ethods}

The fungi were grown on an agarized Capek-Dox culture medium in test tubes at $303 \mathrm{~K}$ for 14 days. Conidia were washed off fungal populations with sterile distilled water onto "Synpor" membrane filters (the conidium layer was $\sim 0.01 \mathrm{~mm}$ thick), following which the collected spores were rinsed with distilled water, dried in $\mathrm{CaCl}_{2}$ desiccator and analyzed by MATR spectroscopy. The filter with a conidium layer on it was settled on the MATR element and pressed to it (the strength with which the filter was pressed to the element was varied until it ceased affecting the intensity of IR bands). Spectra were taken on a 
"Qualimatic" Fourier-transform IR spectrometer ("Digilab") with an MATR element made from KRS-5 crystal and germanium in the shape of a prism.

IR radiation penetrated through a depth estimated as

$$
l=\frac{\Gamma_{i} / n}{2 \pi\left[\sin ^{2} \theta-\left(n_{s}-n_{0}\right)^{2}\right]^{1 / 2}}
$$

where $\Gamma_{i}$ is the radiation wavelength; $n_{s}$ is the refractive index of the crystal; $n_{0}$ is the refractive index of the polymer sample and $\theta$ is the effective angle of incidence equal to $45^{\circ}$.

To calculate the depth of radiation penetration, one has to know the refractive index of conidial membranes. Refractive indexes of the chemical species contained in a membrane differ only slightly, and therefore, one was taken equal to $\sim 1.5$. In the spectral range from 2000 to $1500 \mathrm{~cm}^{-1}$ with the major absorption bands of the membrane constituents in it, radiation penetrates into a KRS-5 crystal through a distance ranging from 0.5 to $0.8 \mu \mathrm{m}$, and starting from $1500 \mathrm{~cm}^{-1}$, the penetration depth increases drastically and attains $1.8 \mu \mathrm{m}$ at $800 \mathrm{~cm}^{-1}$; for germanium this dependence is much smoother: over the range from 2000 to $1500 \mathrm{~cm}^{-1}$, the penetration depth increases from 0.1 to $0.2 \mu \mathrm{m}$, and at $800 \mathrm{~cm}^{-1}$, it measures $\sim 0.3 \mu \mathrm{m}$.

IR spectra of certain chemical components of a conidial membrane, namely, of melanin, chitin (extracted directly from Aspergilius niger), and glycans (Serva-made), were taken from their pellets $(1-5 \mathrm{mg}$ of a membrane component per $300 \mathrm{mg} \mathrm{KBr}$ ). The spectra of phospholipids (of the lipid fraction extracted from Aspergillus niger) were taken in chloroform solutions in a $0.03-\mathrm{cm}$ thick $\mathrm{NaCI}$ cell.

Hydrophobic properties of the conidium surface were judged from its wettability measured in terms of contact angles with an MG-1 horizontal microscope. To this end, we mounted a filter with a dense layer of conidia on it on the microscope table, dripped a drop of water of

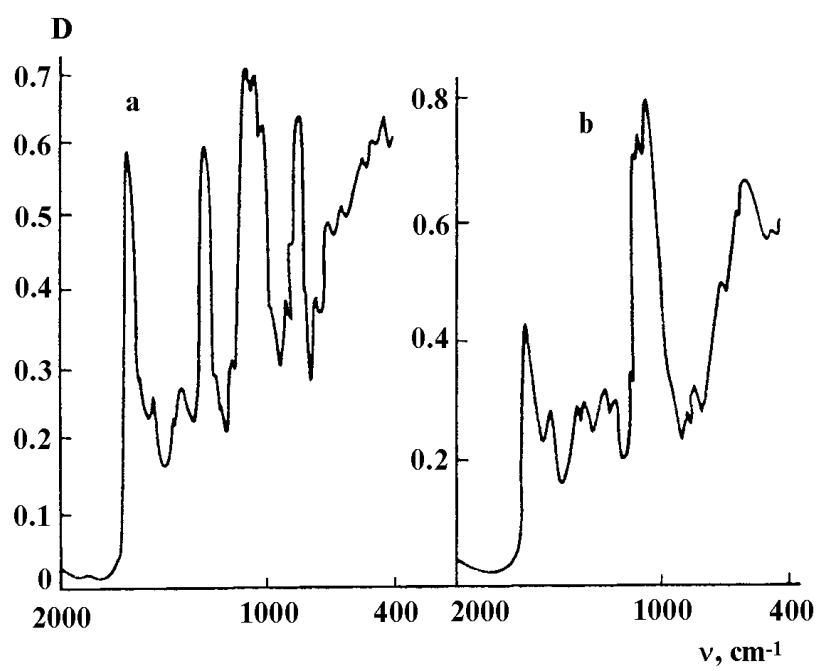

size 1-2 $\mathrm{mm}$ from a syringe on the surface of the layer, and measured the contact angle. The surface roughness was taken into account as follows:

$$
\cos \theta=r \cos \theta_{0}
$$

where $\theta$ is the observed macroscopic angle; $\theta_{0}$ is the true macroscopic angle; $r$ is the surface roughness expressed as a ratio of the true area of the rough surface to its geometric area.

The dependence of the contact angle $\theta$ on the surface roughness was reproduced from the data of [9]. The contact angle either increases or decreases with increasing surface roughness, depending on whether $\theta$ exceeds $85^{\circ}$ on a smooth surface, or is below $60^{\circ}$. In view of these tendencies, the contact angle would be expected to increase on the rigid spherical spores. However, contrary to the expectations, repeated measurements have not revealed any asymmetry of the drop edges, which would be observed, if protruding hemispheres affected the surface roughness. Therefore, we considered it justified not to introduce a correction for the roughness of the surface layer of the filtered conidia.

\section{Results and Discussion}

Representative MATR spectra of conidia of four fungal species are illustrated in Fig. 1. As revealed by the analysis of the measured spectra, the chemical constituents of a conidial membrane can be identified by the absorption bands recorded at 1639-1641, 1550-1560, 1275, 10331100 and $831-835 \mathrm{~cm}^{-1}$. These bands were chosen, because:

- they overlapped very little, if at all, i.e. their positions and intensities were easy to determine;

- their intensities changed dramatically from one fungus type to another, which made them particularly handy for analyzing the quantitative composition of conidial membranes.

Fig. 1. IR spectra of cell membranes of the following microscopic fungi: Thrinchoderma vitide(a), Paecilomyces vatioti(b), Penicillium funiculosum(c) and Aspergillus terreus(d) 
Absorption at 1639-1641 $\mathrm{cm}^{-1}$. In this spectral range, strongly absorb proteins and glycans [6]. The absorption band of proteins, amide I, involves stretching vibrations of $\mathrm{C}=\mathrm{O}(\sim 80 \%)$, stretching vibrations of $\mathrm{C}-\mathrm{N}(\sim 10 \%)$, and bending vibrations of $\mathrm{N}-\mathrm{H}$ of amide groups $(\sim 10 \%)$. From the position of the amide I band one can infer the conformation of a protein molecule; absorption at 1656, 1650 , and $1637 \mathrm{~cm}^{-1}$ testifies to a disordered structure (to the $\alpha$-helix and $\beta$-structure of protein molecules). Absorption in the neighborhood of $1639 \mathrm{~cm}^{-1}$ is also inherent in $\beta$-glycans separated out from cell membranes of the fungi $[10,11]$.

Absorption at $1275 \mathrm{~cm}^{-1}$ This absorption band is due to stretching vibrations of $\mathrm{P}=0$ fragments of phospholipids. Two types of phosphate groups are distinguished, the groups bound to proteins with hydrogen bridges and the free ones: the former absorb at 1350$1220 \mathrm{~cm}^{-1}$, and the latter at $1300-1250 \mathrm{~cm}^{-1}$. Attention is arrested by the fact that the $1275 \mathrm{~cm}^{-1}$ band appeared in the spectra of all the fungi, which indicates the presence of free phosphate groups in them.

Absorption at $1550-1540 \mathrm{~cm}^{-1}$ is due to bending vibrations of $\mathrm{NH}$ groups (amide II) occurring in both proteins and chitin.

Absorption at $831 \mathrm{~cm}^{-1}$ associated with out-of-plane bending vibrations of $\mathrm{C}-\mathrm{H}$ groups indicates the presence of $\alpha$-glycans [12]. It has been shown that various $\alpha$-glycans (mannans, nigerans) isolated from cell membranes of the fungi exhibit absorption peaks in the range from 850 to $830 \mathrm{~cm}^{-1}$.

Absorption at 1070-1050 $\mathrm{cm}^{-1}$ [4] associated with stretching vibrations of $\mathrm{CO}$ groups is inherent in glycans and proteins $[4,5,10]$.

The baseline required to measure band intensities was drawn through the lowest points of peak bases. Extinction coefficients of the membrane constituents at the aforesaid frequencies were calculated from absorption spectra taken at different concentrations of individual substances (chitin, proteins, phospholipids and glycans).

Optical densities of nine species of the microscopic fungi are listed in Table 1.

Concentrations of the chemical components of conidial membranes were estimated under the following assumptions:

- the Lambert-Bouguer-Bragg law in the form $C=\frac{D}{l \varepsilon}$ was observed for all the membrane components (here, $D$ is the optical density, $\varepsilon$ is the extinction coefficient, and $l$ is the depth of radiation penetration);

- extinction coefficients of individual substances (chitin, proteins, phospholipids and $\alpha$-glycan) assume identical values in all the microscopic fungi;

- to avoid errors in reflectance spectra, we used ratios of optical densities of different absorption bands in all instances;

Optical densities of the principal absorption bands of conidial membranes of the microscopic fungi

\begin{tabular}{|c|l|c|c|c|c|c|}
\hline \multirow{2}{*}{ No. } & $\begin{array}{l}\text { Microscopic } \\
\text { fungus }\end{array}$ & \multicolumn{5}{|c|}{ Optical density, arb. units } \\
\cline { 3 - 7 } & $1639-1641 \mathrm{~cm}^{-1}$ & $1550-1560 \mathrm{~cm}^{-1}$ & $1275 \mathrm{~cm}^{-1}$ & $1033-1100 \mathrm{~cm}^{-1}$ & $831-835 \mathrm{~cm}^{-1}$ \\
\hline 1 & $\begin{array}{l}\text { Penicillium } \\
\text { funiculosum }\end{array}$ & $0.35 \pm 0.02$ & 0.01 & $0.36 \pm 0.03$ & $0.28 \pm 0.02$ & $0.39 \pm 0.03$ \\
\hline $\begin{array}{l}\text { Penicillium } \\
\text { chrysogeniu } \\
m\end{array}$ & $0.26 \pm 0.02$ & $0.05 \pm 0.01$ & $0.13 \pm 0.02$ & $0.53 \pm 0.03$ & $0.13 \pm 0.02$ \\
\hline 3 & $\begin{array}{l}\text { Thrichoderm } \\
\text { a viride }\end{array}$ & $0.50 \pm 0.03$ & $0.06 \pm 0.01$ & $0.38 \pm 0.04$ & $0.50 \pm 0.03$ & $0.41 \pm 0.03$ \\
\hline 4 & $\begin{array}{l}\text { Aspergillus } \\
\text { niger }\end{array}$ & $0.30 \pm 0.02$ & $0.08 \pm 0.01$ & $0.20 \pm 0.02$ & $0.40 \pm 0.03$ & $0.14 \pm 0.02$ \\
\hline 5 & $\begin{array}{l}\text { Aspergillus } \\
\text { terreus }\end{array}$ & $0.64 \pm 0.03$ & $0.07 \pm 0.01$ & $0.56 \pm 0.06$ & $0.68 \pm 0.04$ & $0.50 \pm 0.05$ \\
\hline 6 & $\begin{array}{l}\text { Chaetomicin } \\
\text { globusum }\end{array}$ & $0.26 \pm 0.02$ & $0.05 \pm 0.01$ & $0.13 \pm 0.02$ & $0.63 \pm 0.03$ & $0.10 \pm 0.02$ \\
\hline 7 & $\begin{array}{l}\text { Aspergillius } \\
\text { flavus }\end{array}$ & $0.35 \pm 0.02$ & $0.05 \pm 0.01$ & $0.16 \pm 0.02$ & $0.33 \pm 0.02$ & $0.12 \pm 0.02$ \\
\hline 8 & $\begin{array}{l}\text { Penicillium } \\
\text { cyclopilun }\end{array}$ & $0.28 \pm 0.02$ & $0.05 \pm 0.01$ & $0.17 \pm 0.03$ & $0.58 \pm 0.03$ & $0.17 \pm 0.02$ \\
\hline 9 & $\begin{array}{l}\text { Paecilomyce } \\
\text { s varioti }\end{array}$ & $0.33 \pm 0.02$ & $0.08 \pm 0.01$ & $0.13 \pm 0.01$ & $0.55 \pm 0.03$ & $0.08 \pm 0.02$ \\
\hline
\end{tabular}


- mass fractions of the major membrane components added up to unity $C_{a}+C_{1}+C_{a}=1$ (where $C_{a}$ stands for the species containing amide groups, e.g. proteins and chitin, $C_{1}-$ for phospholipids, and $C_{g}$ - for $\alpha$-glycans).

The concentration of phospholipids, $\alpha$-glycans, and other substances containing amide groups were calculated from the ratios of optical densities in the characteristic absorption bands of these species (at 1275 $\mathrm{cm}^{-1}$ for phospholipids, at $831-835 \mathrm{~cm}^{-1}$ for $\alpha$-glycans, and at $1550-1560 \mathrm{~cm}^{-1}$ for amides):

$$
\frac{D_{g}}{D_{l}}=A X, \quad \frac{D_{g}}{D_{l}}=B Y
$$

where $A=\left(\frac{l_{g}}{l_{l}}\right)\left(\frac{\varepsilon_{g}}{\varepsilon_{l}}\right), B=\left(\frac{l_{a}}{l_{l}}\right)\left(\frac{\varepsilon_{a}}{\varepsilon_{l}}\right), X=\frac{l_{g}}{l_{l}}$ and $Y=\frac{C_{a}}{C_{l}}$.

From the balance equation we obtain

$$
C_{l}=\frac{1}{X+Y+1}, C_{a}=\frac{Y}{X+Y+1}, C_{g}=\frac{X}{X+Y+1}
$$

From the aforesaid absorption bands we derived the following estimates:

$$
\frac{l_{g}}{l_{a}}=1.80, \frac{\varepsilon_{g}}{\varepsilon_{l}}=1.6 \pm 0.2, \frac{l_{a}}{l_{l}}=0.20, \frac{\varepsilon_{a}}{\varepsilon_{l}}=0.33 \pm 0.03
$$

The calculated concentrations of phospholipids, $\alpha$ glycans, and amide-containing species (chitin, proteins) are summarized in Table 2.

Absorption bands at 1639-1641 and 1033-1100 $\mathrm{cm}^{-1}$ are composite, i.e., consist of absorption bands of several groups:

$$
D=\sum_{i}\left(\varepsilon_{i} c_{i}\right) l
$$

As revealed by the analysis of the experimental data, these bands involve absorption of amide groups and $\alpha$-glycans.

The total concentrations of the major chemical components in cell membranes of the nine species of microscopic fungi calculated from our data vary over fairly wide ranges: $\alpha$-glycans $0.05-0.25$, phospholipids $0.26-$ 0.72 , and amides 0.01-0.69.

Ratios of membrane components in cells of the fungi, available from the literature, are also widely spread. According to [10], e.g., the concentrations of glycans in the outer and inner membranes of Cimitic conidia related as $3: 2$, which suggests that glycans are mostly contained in the outer membrane. However, the authors of [12] argue that the outer membrane of certain fungal species contains $50 \%$ proteins, $25 \%$ phospholipids, and less than $15 \%$ glycans. We have failed to find any data on the lipid content of fungal membranes in other papers on the subject, which are mostly concerned with the glycan-to-chitin ratio estimated at $6: 1$ [12]. The data gleaned by analysis of conidial membranes are widely spread, primarily because the test samples were variously prepared: by disintegration, dissolution, and biochemical reactions. From NMR study of five species of gramm-positive bacteria it has been concluded [13] that cell membranes of bacteria mostly consist of peptide glycans.

As intimated earlier in this paper, the wettability of fungal membranes in water is estimated in terms of contact angles. To correlate $\theta$ to the membrane composition of each fungus, we constructed the equation relating $\theta$ to the sum of total concentrations of the membrane components taken with the appropriate weight factors $(\alpha, \beta, \gamma)$ :

$$
\log \theta_{i}=\alpha C_{a}+\beta C_{l}+\gamma C_{g}
$$

Table 2

Concentrations of phospholipids, $\alpha$-glycans, and amide-containing components in conidial membranes of the microscopic fungi

\begin{tabular}{|c|l|c|c|c|c|}
\hline \multirow{2}{*}{ No. } & \multirow{2}{*}{ Microscopic fungus } & \multicolumn{3}{c|}{ Mass fraction } & $\begin{array}{c}\text { Contact angle, } \\
\text { grad }\end{array}$ \\
\cline { 3 - 5 } & & Amide & Phospolipid & $\alpha$-Glycans & 130 \\
\hline 1 & Penicillium funiculosum & 0.01 & 0.73 & 0.26 & 109 \\
\hline 2 & Penicillium chrysogenium & 0.56 & 0.33 & 0.11 & 90 \\
\hline 3 & Trichoderma viride & 0.28 & 0.54 & 0.18 & 101 \\
\hline 4 & Aspergillus niger & 0.58 & 0.34 & 0.08 & 120 \\
\hline 5 & Aspergillus terreus & 0.30 & 0.54 & 0.16 & 115 \\
\hline 6 & Chaetomycin globusum & 0.57 & 0.35 & 0.08 & 130 \\
\hline 7 & Aspergillus flavus & 0.52 & 0.39 & 0.10 & 107 \\
\hline 8 & Penicillium cyclopium & 0.49 & 0.38 & 0.13 & 90 \\
\hline 9 & Paecilomyces varioti & 0.69 & 0.26 & 0.05 & \\
\hline
\end{tabular}


By solving the correlation equations for nine types of fungi, we obtained the following weight factors allowing for the contributions of various chemical components to the surface properties of fungal membranes, responsible for their wettability in water, i.e. for hydrophobic properties of membranes:

$$
\alpha_{a}=1.85 \pm 0.05, \beta_{l}=2.6 \pm 0.1 \text {, and } \gamma_{g}=0.75 \pm 0.05
$$

Considering that $\beta$ is $1.5-3.5$ times greater than either of the other two coefficients, hydrophobic properties of the outer membrane mostly depend on phospholipids.

\section{Conclusions}

1. The chemical composition of cell membranes of microscopic fungi destroying polymeric materials is analyzed. The concentrations of the major chemical components - phospholipids, glycans, and amines - in nine types of fungi are estimated.

2. The measured ratios of these components provide an estimate of the hydrophobic properties of conidia, controlling microorganism adhesion to polymer surface and subsequent degradation of polymeric materials.

\section{References}

[1] Gole M.: Miclobiol. Rev., 1986, 5, 95.

[2] Gole M. and Pope L.: The Fungal Spore: Morphogenetic Controls. Academic Press, New York 1981.

[3] Feofilova L.: Kletochnaya Stenka Gribkov. Nauka, Moskwa 1983.

[4] Zaslavskii B., Gulyaeva N., Tul'chinskii V. and Rogozhin S.: Biofizika, 1976, 21, 648.
[5] Zaslavskii B., Gulyaeva N. and Rogozhin S.: Mikrobiologiya, 1977, 46, 511.

[6] Gulyaeva N., Zaslavskii B., Rogozhin S. and Lyapunova T.: Mikrobiologiya, 1977, 46, 667.

[7] Gulyaeva N., Yakovleva M. and Zaslavskii B.: Mikrobiologiya, 1980, 49, 70.

[8] Andrade J. (Ed.): Surface and Interfaction Aspects of Biomedical Polymers. Surface Chemistry and Physics. Plenum Press, New York-London 1985.

[9] Busseher C., Pelt A., Van Baer P. et al.: Colloid \& Surface, 1984, 9, 319.

[10] Chirgadze Yu.: Infrakrasnye Spektry i Struktura Polipeptidov i Belkov. Nauka, Moskwa 1964.

[11] Shcherbukhin F.: Usp. Biol. Khim., 1968, 79, 198.

[12] Michell J. and Scurfield J.: Aust. J. Biol. Sci., 1989, 23, 345.

[13] Marshall K. (Ed.): Microbiological Adhesion and Aggregation. Dahlem Conferenzen, Springer-Verlag, Berlin Heidelberg - New York - Tokyo 1984.

[14] Zaikov G.: Biochemical Physics. Nova Science Publ., New York 2007.

\section{БІОДЕГРАДАЦЯ ПОЛІМЕРНИХ МАТЕРІАЛІВ І АДГЕЗІЙНІ ВЛАСТИВОСТІ КЛІТИН МІКРООРГАНІЗМІВ}

Анотація. Проаналізовано хімічну структуру клітинних мембран мікроскопічних грибків, щзо руйнують полімерні матеріали. Для дев'ятьох типів грибків встановлені концентрації основних хімічних компонентів - фосфоліпідів, глісанів і амінів. Одержані дані дозволяють оцінити гідрофобні властивості конідї, цьо даєможливість контролювати ї̈адгезію до полімерних поверхонь та подальиу деградацію полімерних матеріалів.

Ключові слова: біодеградація, полімер, матеріали, адгезія, властивості, клітини, мікроорганізми. 